\title{
PROVINCIAL INTERESTS AND POLITICAL INTEGRATION: VOTING IN THE FRENCH MAASTRICHT REFERENDUM
}

\author{
D. Andrew Austin
}
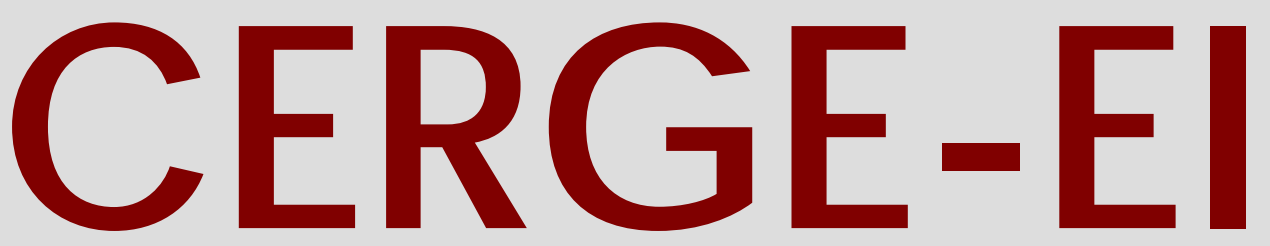

Charles University CenterforEconomic Research and Graduate Education Academy of Sciences of the Czech Republic Ec onomic s Institute 


\title{
Working Paper Series \\ (ISSN 1211-3298)
}

281

\section{Provincial Interests and Political Integration: Voting in the French Maastricht Referendum}

\author{
D. Andrew Austin
}

CERGE-EI

Prague, November 2005 
ISBN 80-7343-074-6 (Univerzita Karlova v Praze, CERGE)

ISBN 80-7344-063-6 (Národohospodářský ústav AV ČR, Praha) 


\title{
Provincial Interests and Political Integration: Voting in the French Maastricht Referendum
}

\author{
D. Andrew Austin*
}

November 2005

\begin{abstract}
In September 1992 French voters in a national referendum approved the Maastrict Treaty, which instituted several provisions for closer European integration including creation of the Eurozone. This paper analyzes political and economic forces that affected French voters, and the links between the progress of European integration and changes in redistributive spending. Conventional wisdom ascribes the persistence of the Common Agricultural Program subsidies to the political power of farmers, although direct evidence of this has been sparse. The statistical analysis here finds that support for European integration is weaker, other things equal, in areas where farmers were most affected by the MacSharry reforms, which reduced some support prices and began the process of 'decoupling' agricultural subsidies from production. Results also show previous support for European integration and pro-European politicians are correlated with stronger support for ratification, as are higher incomes and higher proportions of non-natives. The results are consistent with the view that European integration provides voters and taxpayers with a way to limit the influence of interest groups by shifting decisionmaking from a national to a supranational arena.
\end{abstract}

JEL Codes: H230, D720

Keywords: referendum, agricultural subsidies, European integration, voting

Acknowlegements: This work has benefited from comments from Thilo Bodenstein, Libor Dusek, Randy Filer, Stepan Jurajda, Jan Kmenta, participants at the Jean-Monnet Lecture at the Freie Universitaet in Berlin, the IIPF meetings in Prague, the 2003 European Public Choice meetings and at an internal brown bag seminar. Thanks to Sébastien Perez-Duarte and Erwan Quintin for help with data collection. Marcel Ngambi, Ervin Mercuri, Madina Ikaeva and Magda Borys provided expeditious research assistance. Remaining errors are mine.

* A joint workplace of the Center for Economic Research and Graduate Education, Charles University, Prague, and the Economics Institute of the Academy of Sciences of the Czech Republic.

Address: CERGE-EI, P.O. Box 882, Politických vezňů 7, Prague 1, 111 21, Czech Republic

Email: Andrew.Austin@cerge-ei.cz 


\begin{abstract}
Abstrakt
V záŕí 1992 schválili francouzští voliči v referendu Maastrichtskou dohodu, což následně dalo za vznik několikerým opatřením pro užší evropskou integraci včetně vytvoření Eurozóny. Tato studie analyzuje politické a ekonomické síly, které ovlivnily francouzské voliče, a také spojení mezi procesem evropské integrace a změnami v redistribučních výdajích. Přes relativní nepřesvědčivost důkazů je přetrvávající struktura dotací v rámci Společné zemědělské politiky přisuzována politické síle zemědělců. Naše statistická analýza zde prokazuje, že podpora evropské integrace je slabší, za jinak neměnných okolností, v územích, kde byli zemědělci nejvíce ovlivněni MacSharryho reformou. Ta omezila dotované ceny a započala proces „odbourávání" zemědělských dotací ve výrobě. Výsledky dále potvrzují, že silnější podpora ratifikace dohody je svázána s dř́vější podporu evropské integraci a pro-evropským politikům stejně jako s vyššími př́ijmy a vyšším podílem nedomorodých obyvatel. Výsledky jsou konzistentní s názorem, že evropská integrace poskytuje voličům a daňovým poplatníkům cestu jak omezit vliv zájmových skupin přesunutím rozhodovacích procedur z národní do mezinárodní arény.
\end{abstract}




\section{Introduction}

\subsection{The French Maastricht Referendum}

On September 20, 1992 French voters narrowly approved the Maastricht Treaty. Ratification of the Maastrict treaty, which transformed the European Community into the European Union, was a major step towards political and economic integration of Europe. This paper analyzes voting behavior in this referendum, and in particular, focuses on the interaction between redistributive policies and the delegation of decisionmaking power between a national government and a supranational body. This paper presents a model that assumes voters make rational and self-interested decisions about European integration generate predictions that are supported by empirical analysis of voting patterns in this referendum. This model assumes a forward-looking voter makes a decision whether to support or oppose ratification of the Maastricht Treaty based not only the effects of specific policy measures contained in the Treaty, but also considering how the Treaty would affect the EU membership and the locus of decisionmaking, thus altering outcomes in the affected policy areas.

Many referendums allow voters to decide directly what policy or law should be chosen or whether a certain amount should be spent or borrowed a given program. ${ }^{1}$ The French Maastricht vote is an example of a less common type of referendum in which voters chose where political, economic and social policies decisions would be taken in the future. EU-level decisions made through the workings of a different constellation of political and administrative actors can be expected to differ from decisions made at the national level. Incentives facing these EU decisionmakers differ, for better or worse, from those facing national decisionmakers, decisions made in Brussels or Strasbourg will differ from decisions that would have been made in national capitals.

Redistributive policy has played an important role in European integration. The Common Agricultural Policy (CAP), which consumes roughly half of the EU's budget, formed a crucial part of the Treaty of Rome. Each following round of European integration has been accompanied by significant changes or expansions of redistributive programs, even when stipulations were agreed to be-

\footnotetext{
${ }^{1}$ Butler and Ranney argue the plural should be "referendums."
} 
forehand that these programs should not be changed. The model links voting behavior with changes in the political center of gravity resulting from deeper or wider European integration and the pecuniary interests of beneficiaries and net fiscal losers. Predictions of this model are strongly supported by the empirical results, which uses a rich data set on 300 local areas that includes variables representing past voting behavior, economic indicators, subsidies and urbanization. Commentators at the time of the vote and political scientists after the vote overlooked the importance of redistributive politics, and instead emphasized the role of monetary integration and voters' attitudes towards President Francois Mitterand, who called the referendum. Few of these writers noted any link between voting patterns and redistributive spending programs.

The rest of the paper discusses the Maastricht treaty and redistribution in the European Union, with particular reference to the CAP. Then the model of how voters decide whether to support European integration or not is set out. The specification of the voter's decision rule is then discussed in the context of the politics of European integration. After a discussion of aggregation issues and a description of the data set, the empirical analysis is presented. The last section provides a discussion of voting, redistribution and European integration and a conclusion.

\subsection{Maastricht and Redistribution}

Like every other major initiative for European integration, the Maastricht treaty required major adjustments in patterns of redistribution, both within and among member countries. ${ }^{2}$ The 1991 Maastricht Treaty is a complex document. Along with the preceding 1987 Single European Act, it created common European policies in several key areas. The most prominent changes were coordinated macroeconomic policies leading to a common currency and measures designed to deepen the European markets by dismantling local and national barriers. The Treaty also limited intra-national redistribution by imposing restrictions on industrial policy and by inclusion of the Stability Pact, which threatened tough

\footnotetext{
${ }^{2}$ For example, during accession negotiations in 2002, the German Chancellor Gerhard Schoeder said, "Whoever wants to change anything in the compromise which the EU Draft Constitution represents must consider the connection between their position and the EU financing negotiations which begin in the same year. Whoever does not see that connection must learn that such attitudes will not go unpunished."
} 
sanctions for member states that violated guidelines for government borrowing and other fiscal policies. Thus integration has important consequences for local voters through changes in subsidy systems or limitations on national efforts to reduce unemployment via industrial policy. ${ }^{3}$

The Maastricht Treaty also laid the groundwork for the eventual eastward expansion of the EU. While in 1992 the economic and political prognosis for the former members of COMECON and the Warsaw Pact was yet unclear, the outlines of a expansion program had already started to emerge. As changes in membership bring changes in political dynamics and in outcomes, ratification of Maastricht in part involved assessing whether expanding the EU was a good idea. For example, a round of reforms in the Common Agricultural Policy (CAP) came after the UK's entry in the early 1970s, which temporarily reduced payments to French farmers substantially. Spain and Portugal, after entering the EC in 1986, joined forces with Ireland and Greece to force a shift to redistributive spending in the form of 'structural funds' at the expense of an expanded CAP (Baldwin and Wyplosz 2003). ${ }^{4}$

The promise of faster economic growth and greater political security provide substantial motivation for European integration, but the uneven distribution of these benefits means new agreements will not occur without protracted negotiations, arm-twisting and horse-trading. Increased competition and other reforms create losers as well as winners. If losing regions, industries and workers can block or stall movement towards greater economic and political unity, change only occurs when the political system finds ways to extract a portion of the gains of winning regions, industries and workers in order to softening or overcoming opposition. If redistribution allows greater progress towards growth-friendly policies by softening the opposition of economic losers, it also inevitably creates efficiency losses. Redistributive schemes closely associated with various phases of European integration are large, and the Common Agricultural Policy (CAP) is the largest item in the EU's budget. Even though the CAP was at most a peripheral issue in the discussion of the Maastricht Treaty in France, the mag-

\footnotetext{
${ }^{3}$ The Maastricht Treaty also contained provisions affecting a wide range of issues, such as foreign policy and security policy. In retrospect it is clear that these provisions have been less important than those affecting economics and governance. Meon (2005) argues that the debate over the Maastricht referendum centered on the implications of monetary union.

${ }^{4}$ From 1973 to 1980 the value of subsidies (in $1983 \mathrm{FFs}$ ) fell from 35.5 to 22.6 billion. See Table 70 and pp.136-139 CERC (1985)
} 
nitude of the program guaranteed that major changes to European governance would eventually also affect the CAP.

\subsection{Common Agricultural Program}

The CAP redistributes large amounts of income from European consumers and taxpayers to favored groups of agricultural producers. Like other agricultural subsidy programs in advanced industrial countries, the CAP has kept agricultural prices above world prices, generated huge surpluses and created recurrent budget crises for the European Union (EU). Complicated administrative procedures and several rounds of attempted reforms have done relatively little to address the fundamental financial problems. The power and influence of farmers and farm lobbies is the explanation for the resilience of CAP to fundamental reform. Agricultural interests influence elected officials and government authorities through many channels, including lobbying, direct demonstrations, financial support for political campaigns and electoral behavior. This paper analyzes the electoral channel, and finds that variations in CAP subsidies in France are systematically related to voting behavior in the Maastricht referendum.

Article 39 of the Treaty of Rome states the CAP should ensure "the optimum utilization of all factors of production," stable markets, certainty of food supplies and that customers are supplied with agricultural products "at reasonable prices." El-Agraa (1990, p.194) notes that these goals are "mutually contradictory." Gylfason (1995) surveys 14 studies that assess the total economic costs of the CAP. Partial equilibrium estimates of the cost to the EU economy ranged from $0.3 \%$ to $1.3 \%$ of GDP, and general equilibrium estimates ranged from $1.4 \%$ to $3.3 \%$ of GDP. Tokarick (2005) presents partial and general equilibrium estimates of gains to the European Union from agricultural liberalization in developed countries of $\$ 32$ billion or $0.2 \%$ of GDP.

Viewing the costs of the CAP in isolation may be misleading because it originated as part of a larger political, economic and diplomatic bargain. Without the transfer of resources to agricultural producers and regions, which favored France and Italy, the opening of markets for manufactured goods, which benefited Germany, would have been impossible. Germany in the early 1950s needed to accelerate manufactured exports, and favored a free trade area approach to economic integration, while France with about a quarter of its population working 
in agriculture and a weaker manufacturing sector favored a customs union approach. At the May 1955 Eicherscheid conference, the German delegation added an agricultural policy proposal in order to gain French support for what became the Treaty of Rome (Milward 1993, Moravcsik 1998, pp.98-112). To the extent that the Treaty of Rome would not have occurred without a side payment in the form of a major agricultural subsidy program, the costs and inefficiencies of the CAP must be counterbalanced with other benefits of European integration.

Because trade barriers lowered via international agreements are not easily reversed, transfers to France and other agriculturally oriented countries were embedded in difficult-to-dismantle administrative structures. A simpler and more transparent contract among manufacturing and agricultural countries that transferred income to farming regions in exchange for more open trade in manufactures might have been more efficient, but such an arrangement would have lacked the credibility-enhancing stability of a complex bureaucratic mechanism. The inflexibility of the CAP, which has frustrated round after round of reforms, may have played an important role in creating a solid basis for European integration.

\subsection{CAP and Maastricht}

During the public debate over Maastricht ratification the CAP was poised to undergo significant changes. After disagreements over farm subsidies and agricultural trade barriers caused Uruguay Round trade negotiations to collapse in December 1990, the European Community came under increasing pressure to make serious changes in the CAP. ${ }^{5}$ The EU farm commissioner Ray MacSharry proposed reforms promising a significant restructuring of parts of the CAP, which were adopted in May 1992, freeing the way for the 1993 agreements that concluded the Uruguay Round. These negotiations over agricultural liberalization and CAP appeared to move along a different track from the process of European integration.

At first glance, the CAP and the ratification of the Maastricht Treaty are unrelated. The main features of the Maastricht comprises plans for monetary union, some unsuccessful steps towards a unified foreign policy, expanded powers for European Community institutions, and plans for new 'cohesion' funds. Of course, the scale of the CAP's finances guarantees it a role in the European inte-

\footnotetext{
${ }^{5}$ The first internal European Commission document outlining a CAP reform plan was issued on the same day as the breakdown of the Uruguary Round talks (Paarlberg 1996).
} 
gration politics and at least an implicit role in French domestic politics. In 1992 French agriculture received 12.54 billion euro through the CAP and other sources and the average farm [exploitation] received over 15,000 euro in support (Ministry of Agriculture 2003). However, textbook summaries of the Maastricht treaty (Swann 1996, pp.119-141) contain no mention of the CAP. The post-referendum wrap-up articles in Le Monde contain no mention of the CAP. Academic articles such as Criddle (1993), Schneider and Wietsman (1996), Franklin, der Eijk and Marsh (1996) contain no mention of the CAP. Discussions of the CAP in the 1990s, such as Jovanovič (1997), Artis and Lee (1994), Barrass and Madhavan (1996) contain no mention of Maastricht. Swann (1996) noted the inclusion of cohesion funds for Spain in the Maastricht agreements, demonstrating another link between integration and changes in patterns of redistribution, but made no connection between Maastricht and the CAP. Dreyfus (1993) noted rural areas tended to vote 'Non,' but also did not mention the CAP. Mazzucelli (1997) claimed the rural 'Non' reflected farmers' opposition to CAP reform.

Results presented in the empirical analysis below support the view that CAP and opposition to European integration were linked. Presuming voters take farm subsidy levels as given, these subsidies had a significant effect on voting behavior in the Maastricht referendum of 1992, even though a superficial analysis would suggest no link between the content of that agreement and the CAP. The CAP could affect political choices in many different ways. CAP reform proposals typically result in strong reactions from farmers' organizations, such as dumping rutabagas or other types of produce on roads or airports, but these direct actions are not clearly linked to policy decisions. Farm unions play a prominent role in descriptions of CAP politics (Moravcsik 1996, p.98), suggesting agricultural producers exert influence through the channel of interest group politics. Electoral politics, as the results presented below demonstrate, provide another channel through which CAP supporters can wield influence on politicians and policy outcomes. If these agricultural interests threaten to withdraw support from politicians or policies that might lead to reduced subsidy payments, or if they reward those who increase payments, the CAP represents an implicit exchange of income redistribution for political support. Or this may be an example of 'pocketbook voting' in which voters whose incomes have risen due to transfers and subsidies reward with their support politicians who presided over these programs. 
A more sophisticated, forward-looking variant of pocketbook voting is that voters care about where decisions will be taken that will affect their material interests. The US strategy in the Uruguay Round was to shift discussion of agriculture subsidies and trade barriers away from domestic institutions captured by farm interests, such as Agriculture Ministries, to international institutions concerned with trade, such as GATT, WTO which were more interesting in agricultural liberalization (Paarlberg 1996). ${ }^{6}$ Farmers may well have understood this strategy, and may have voted to prevent institutional changes that would allow such changes of venue that would shift discussion of farm issues towards a less friendly forum. A model describing the choice of a voter facing an initiative that would change the locus of political control is now presented.

\section{A model of referendum voting behavior}

This section presents a model of how individuals decide to vote over political integration. A country is represented by a set of $N$ individuals, who receive endowments $\left\{\omega_{i}\right\}_{i \in N}$ and share the utility function

$$
U\left(c_{i}, g, \nu_{i} I\right)
$$

where $c_{i}$ is private consumption, $g$ is consumption of a publicly provided good and $y_{i}$ represents a taste for integration, so that

$$
I=1 \text { if integration occurs, otherwise } I=0 \text {. }
$$

Without loss of generality let $U\left(c_{i}, g, 1\right)>U\left(c_{i}, g, 0\right)$. If $\nu_{i}>0$ then person $i$ has a taste for integration. The publicly provided good $g$ is produced using a linear technology $f\left(\frac{R}{N}\right)=\frac{f^{\prime}}{Q} \cdot\left(\frac{R}{N}\right)$, where $N$ is the number of people in the original population and $Q$ is an index of factor prices. Government revenue is $R=\tau \sum_{i \in N} \omega_{i}$ and government expenditures must equal revenues. Person $i$ enjoys $k_{i} \cdot f\left(\frac{R}{N}\right)$ units of public provision where $\sum_{i \in N} k_{i}=1$. The parameters $\left\{k_{i}\right\}_{i \in N}$ are taken as fixed. Public production is financed by proportional tax on endowments,

\footnotetext{
${ }^{6}$ Paarlberg however is skeptical that this strategy resulted in greater liberalization in farm policy than could have been acheived by purely domestic means. In particular, Uruguay round limits do not seem to have seriously constrained farm subsidies in major agricultural countries.
} 
so the budget constraint for an individual is

$$
\omega_{i} \cdot(1-\tau)-c_{i} \geq 0
$$

Let $\bar{\omega}$ be tax base per head, so

$$
\bar{\omega}=\frac{\tau}{N} \sum_{i \in N} \omega_{i}
$$

An individual's most preferred tax rate, holding the size of the jurisdiction fixed, is characterized by the problem

$\operatorname{Max} U\left(c_{i}, g, y_{i}\right)$
s.t. (i) $\omega_{i} \cdot(1-\tau)-c_{i} \geq 0$
(ii) $k_{i} \cdot f^{\prime} \cdot(\tau \bar{\omega})-g \geq 0 \quad(\mu)$
(iii) $c_{i} \geq 0$

First-order conditions for an interior solution are

(a) $u_{C}(\tau, \omega)-\lambda=0$

(b) $u_{G}(\tau, \omega)-\mu=0$

(c) $-\lambda \cdot \omega_{i}+\mu \cdot k_{i} \cdot \frac{f^{\prime}}{Q} \cdot \bar{\omega}$.

These yield the condition

$$
\frac{u_{G}(\tau, \omega)}{u_{C}(\tau, \omega)}=\frac{Q}{f^{\prime}} \cdot \frac{\omega_{i} / \bar{\omega}}{k_{i}}
$$

where $\omega_{i} / \bar{\omega}$ is person $i$ 's wealth divided by average wealth and $\left(Q / f^{\prime}\right)$ is the marginal cost of public provision. The marginal cost of public provision is $\left(\frac{Q}{f^{\prime}}\right)$ and person $i^{\prime}$ s tax price for input for public provision is $\frac{\omega_{i} / \bar{\omega}}{k_{i}}$.

The relationship among individual preferences is assumed to obey a single-crossing property that requires marginal rates of substitution between public and private consumption for any two individuals, weighted by the inverse of the tax price for public inputs, to follow the same ordering as endowments.

Assumption: If an individual $i$ has a lower tax price for public inputs than voter $j$, so $\frac{\omega_{i}}{k_{i} \cdot \bar{\omega}}<\frac{\omega_{j}}{k_{j} \cdot \bar{\omega}}$, then 


$$
\left.\frac{k_{i}}{\omega_{i} / \bar{\omega}} \cdot \frac{u_{G}\left(\tau, \omega_{i}\right)}{u_{C}\left(\tau, \omega_{i}\right)}\right|_{\tau_{j}^{*}}>\left.\frac{k_{j}}{\omega_{j} / \bar{\omega}} \cdot \frac{u_{G}\left(\tau, \omega_{j}\right)}{u_{C}\left(\tau, \omega_{j}\right)}\right|_{\tau_{j}^{*}}
$$

where $\tau_{j}^{*}$ is the preferred tax rate for $j$.

This assumption ensures that most preferred taxes rates will fall as the tax price rise and implies that a version of the median voter theorem holds for a simple voting-process.

The integration decision takes two stages. First an election determines whether integration occurs with a another society comprising $M$ individuals. $^{7}$ Then a vote to determine taxes and public goods levels is held. Individual $i$ chooses either $Y$ or $N$ in the first round and $\tau_{i} \in[0,1]$ in the second round. Integration occurs if a simple majority of individuals choose $Y$. In the second round the median submitted tax rate is implemented. If this is not unique because the number of voters is even the lower median rate is chosen. Subgame perfect Nash equilibrium in undominated strategies is the solution concept. As usual, best responses are determined using backward induction. ${ }^{8}$ In the second round each voter submits his most-preferred tax rate. In equilibrium the voter with the median tax price for public inputs, either for the original society or for the consolidated society depending on the results of the first round, will be decisive in the second round. In the first round voters anticipate results in the second round. The voter with the median tax price for public inputs will not necessarily be decisive because of the effect of other voters' tastes for integration. ${ }^{9}$

Integration changes the identity of the decisive voter and the average endowment. By affecting whose preferences prevail and what the financial constraints will be, integration influences the voting process and the choice of tax and public provision levels. Let the no-integration fiscal variables be $\left(c_{i}^{S E P}, g^{S E P}\right)$ and the post-integration fiscal variables be $\left(c_{i}^{I N T}, g^{I N T}\right)$. The effects of a small

\footnotetext{
${ }^{7}$ Another approach would be to model integration as a country's choice to put some fraction of public expenditures under the control of a multinational body. The multinational body would then make public provision decisions based on how much each nation contributed. However, the predictions of this model would be the same as the simpler model presented here.

${ }^{8}$ Actually a somewhat stronger condition is required to ensure that coalitions, not just individuals, do not make non-credible threats.

${ }^{9}$ One could also imagine that if integration occurs that some bargaining process determines outcomes. The direction of effects will be the same for typical bargaining solutions such as the Nash cooperative solution. However, the two-stage game is unlikely to be dominance soluble, creating technical complications with little or no change in the results.
} 
integration may be approximated by a first-order Taylor expansion:

$$
\begin{aligned}
\Delta U\left(c_{i}, g, I_{i}\right) \equiv & U\left(c_{i}^{I N T}, g^{I N T}, 1\right)-U\left(c_{i}^{S E P}, g^{S E P}, 0\right) \\
& \text { or } \\
\Delta U\left(c_{i}, g, I_{i}\right) \approx & u_{C}\left(c_{i}^{I N T}-c_{i}^{S E P}\right)+k_{i} \cdot u_{G}\left(g^{I N T}-g^{S E P}\right)+u_{I} \cdot \nu_{i} .
\end{aligned}
$$

Person $i$ votes for integration if this expression is nonnegative. Rearranging terms gives

$$
\left(c_{i}^{I N T}-c_{i}^{S E P}\right)+k_{i} \cdot \frac{u_{G}}{u_{C}}\left(g^{I N T}-g^{S E P}\right)+\frac{u_{I}}{u_{C}} \cdot \nu_{i} \geq 0 .
$$

Let $\mu^{S E P}$ be the original decisive voter and and $\mu^{I N T}$ be the decisive voter if integration occurs, and let $\tau_{S E P}^{*}$ be the preferred tax rate for $\mu^{S E P}$ given tax base per head of $\bar{\omega}^{S E P}$, and $\tau_{I N T}^{*}$ be the preferred tax rate for $\mu^{I N T}$ given tax base per head of $\bar{\omega}^{I N T}$. Then person $i$ favors integration if

$$
\left[\left.\frac{f^{\prime}}{Q} \cdot \frac{u_{G}}{u_{C}}\right|_{\tau_{S E P}^{*}}-\frac{\omega^{i}}{k^{i} \cdot \bar{\omega}^{S E P}}\right] \cdot \bar{\omega}^{S E P} \cdot \Delta \tau^{*}+\left.\left(\tau_{I N T}^{*} \cdot \bar{\omega}^{A D D}\right) \cdot \frac{f^{\prime}}{Q} \cdot \frac{u_{G}}{u_{C}}\right|_{\tau_{S E P}^{*}}+\left.\frac{u_{I}}{u_{C}}\right|_{\tau_{S E P}^{*}} \cdot \nu_{i} \geq 0
$$

where $\bar{\omega}^{A D D}$ is the added tax base gained through integration and $\Delta \tau^{*}=\left(\tau_{S E P}^{*}-\tau_{I N T}^{*}\right)$ is the change in tax rates. The first term represents value of public provision net of forgone private consumption. The expression in square brackets is zero for the no-integration decisive voter. For voters with a lower tax price for public inputs than the no-integration decisive voter the corresponding term in the equation determining their voting decision will be positive. That is, if integration causes taxes to rise, voters with a lower tax price will value the added public consumption more than the no-integration decisive voter. The second term represents the value of the gain in tax base acquired through integration. The last term reflects the voter's taste for integration.

\section{Specification}

\subsection{The Model and Predictions}

The model indicates that the probability an individual chooses to vote for integration depends on how the fiscal situation would change, on his tax price 
and on his taste for integration. The voter's index function can be rearranged as follows

$$
\left.\left[\frac{f^{\prime}}{Q} \cdot \bar{\omega}^{S E P} \cdot \Delta \tau^{*}+\frac{f^{\prime}}{Q} \cdot\left(\tau_{I N T}^{*} \cdot \bar{\omega}^{A D D}\right)\right] \cdot \frac{u_{G}}{u_{C}}\right|_{\tau_{S E P}^{*}}-\left[\bar{\omega}^{S E P} \cdot \Delta \tau^{*}\right] \cdot \frac{\omega^{i}}{k^{i} \cdot \bar{\omega}^{S E P}}+\left.\frac{u_{I}}{u_{C}}\right|_{\tau_{S E P}^{*}} \cdot \nu_{i} \geq 0
$$

The terms in square brackets are constant across voters. The first term in square brackets shows the effect of integration on the tax base, which is the sum of a change in tax effect and a change in tax base effect. As the Stability Pact's intention was to reduce debt and deficits of EU countries, thus putting downward pressure on government spending, presumably voters expected $\Delta \tau^{*}$ to be negative. On the other hand, France's per capita income has been slightly above the average of the EU 15. To the extent that European integration shifts decisionmaking from Paris to Brussels, so that the decisive voter among existing EU countries becomes more relevant at the expense of the decisive voter in France, the relevant per capita income, and thus $\bar{\omega}^{A D D}$, falls slightly. As the Maastricht Treaty also paved the road to accession of 10 additional countries, all with much lower per capita incomes, voters might reasonably have expected approval of the referendum to lead to economic and political integration which would result in a lowering of the average EU income for the foreseeable future, even if integration led to higher income growth rates in each country.

More particularly, because France has traditionally been a net beneficiary of the CAP, either shifting decisionmaking to Brussels which would presumably give more leverage to countries which were net contributors, or expanding the EU eastwards to include heavily agricultural countries such as Poland, voters might have expected approval of the Maastricht Treaty to lead to a changed political environment which could create pressure for lower CAP subsidies. Indeed, net contributor countries have produced a stream of proposals for reducing CAP subsidies. To sum up, the first term in square brackets consists of two terms, which based on analysis of the situation, are probably both negative. The variable part of the first term represents taste for public provision. The model then predicts that those with a stronger taste for public good are more likely to vote 'Non.'

The second term in square brackets also includes $\Delta \tau^{*}$, and is thus expected to be negative. The variable part varies directly with an individual's tax price and inversely with his or her relative share of public benefits. The model 
then predicts that those with higher incomes are more likely to vote 'Oui' and voters receiving higher levels of benefits are more likely to vote 'Non.' As noted before, the third term represents the taste for European integration.

For the empirical work the probability of a 'Oui' vote is represented by the expression

$$
\operatorname{Pr}\left(\text { Oui }_{i}\right)=\Lambda\left(\beta_{0}+\beta_{1} \cdot \text { PubProvTaste }_{i}+\beta_{2} \cdot \text { ProInteg }_{i}+\beta_{3} \cdot \text { NetBenefits }_{i}\right)
$$

where $\Lambda(\cdot)$ is a logit function. PubProvTaste ${ }_{i}$ is a vector of variables reflecting taste for public provision, Prointeg $_{i}$ is a vector of variables reflecting attitudes towards European integration, and NetBenefits ${ }_{i}$ is a vector of variables reflecting differential benefits from public provision and tax prices. Of course, some variables used in the empirical analysis, such as unemployment status and political voting history, may affect more than one category.

\subsection{Aggregation}

Because individual ballots are unobserved the estimation is run on aggregated voting data from cities and rural parts of département. France is divided into 100 départements, which are level of administrative intermediate to regions and cantons. ${ }^{10}$ If each individual's vote is statistically independent it can be shown that aggregate voting behavior is described by

$\ln \left(\frac{V_{j}}{1-V_{j}}\right)=\beta_{0}+\beta_{1} \cdot$ PubProvTaste $_{j}+\beta_{2} \cdot$ ProInteg $_{j}+\beta_{3} \cdot$ NetBenefits $_{j}+\lambda_{j}+\varepsilon_{j}$

where $V_{j}$ is the proportion voting 'Oui' in area $j$. Independent variables indexed by $j$ represent area averages, $\varepsilon_{j}$ is an i.i.d. error term representing unobserved heterogeneity and $\lambda_{j}$ is a heteroskedasticity correction. Under the given assumptions, this specification permits interpretation of the regression coefficients as parameters of the underlying utility function of a representative voter (Greene 2003, p.686-7). Snyder (2005) proves a similar linearity result in a context where

\footnotetext{
${ }^{10}$ The system of départements was established 1790. New boundaries cut across the boundaries of the provinces, the key administrative division of the French monarchy, to minimize the influence of old loyalties and allegiances (Wikipedia 2005). To the extent that provincial differences persist, the way these boundaries were drawn reduces unobserved heterogeneity among départements.
} 
the relative effects of an electoral proposition can be represented as a point in Euclidean space, voters have Euclidean preferences (i.e. spherical indifference surfaces) and are slightly uncertain about the true effects of the proposition, and voter ideal points are symmetrically distributed in each district.

Because individual ballots are unobserved the estimation is run on aggregated voting data from départements and cities. Because départements differ in size the aggregation process creates heteroskedasticity. That is, the aggregation of votes is here treated as a sampling process and unobserved heterogeneity among départements provides another source of variance. Amemiya and Nold (1975) propose a two-stage grouped-logit estimator, asymptotically equivalent to the maximum likelihood estimator, which uses a weighting scheme based on the square root law along with a correction for unobserved heterogeneity. However, Dickens (1990) notes that weighting observations by the square root of group size may lead to biased and inefficient estimates because individual choices within an unit of aggregation are likely to be correlated. Unless individual choices within the group are believed to be uncorrelated, he argues, using unweighted data provides better results. Voting choices within a given geographic district may be correlated for many reasons.

When sharp group differences such as race divide voters and where voters in districts with high proportions of minorities act differently than in districts with low proportions of minorities, then estimates using grouped data are biased (Ansolabehere and Rivers 1995). However, these factors are much less relevant here. ${ }^{11}$ Racial tensions in France during the early 1990s were probably much lower than in districts analyzed in the US voting rights literature. The Maastricht referendum split the political establishment and parties, and so did not divide voters along the lines of usual politics. Biases in group-data estimators are said to result from differences in behavior of minority voters in districts containing many minorities from behavior in districts containing high proportions of minorities. Similarly, differences in non-minority voter behavior across such districts may also bias estimates. If one takes not being a native French citizen as a proxy for minority status, the distribution of minorities is relatively even. ${ }^{12}$ In the present dataset only two city observations are 'majority minor-

\footnotetext{
${ }^{11}$ Sharper social divisions may exist in some areas excluded from the dataset, such as Corsica, the overseas colonies and Paris.

${ }^{12}$ The French census of the population has no race question.
} 
ity' and the highest proportion of non-natives among département observations is about a quarter. Thus the bias caused by strongly racially polarized voting in highly segregated districts seems unlikely to occur here. Furthermore, this aggregation bias is aggravated by the absence of covariates (Calvo and Escolar 2003). ${ }^{13}$ While US voting data are difficult to link to sociodemographic data because electoral and administrative boundaries almost always differ, in France they coincide. Therefore matching French voting data with covariates is relatively straightforward.

Binkley (1992) examines finite sample properties of grouped heteroskedasticity estimators using Monte Carlo techniques. He finds that the usual PaganBreusch test overstates errors and proposes a modified Pagan-Breusch test as a reasonable compromise between tests sensitive to Type I errors and those sensitive to Type II errors. This suggestion is implemented by running separate regressions for cities and for départements, and then pooling errors for use in calculating a modified Pagan-Breusch test. For various specifications the hypothesis of no heteroskedasticity was rejected. The Amemiya-Nold estimator corrects for effects of within-group heterogeneity, which the estimators that Dickens considers do not. However, because the observation with the smallest population has about 20,000 residents, the Amemiya-Nold estimates are nearly identical to those obtained by a naive weighting scheme. ${ }^{14}$ For these reasons the empirical analysis employes OLS along with robust standard errors.

\subsection{Voting and Variables}

Previous research suggests that French voters, like those in other countries, respond to economic interests and conditions. Lewis-Beck (1983) used Eurobarometer survey data to find that voting intentions in French legislative elections were correlated with measures of ideology, attitudes towards inflation and job opportunities, and unemployment experience. Eurobarometer data has the advantage that it avoids possible problems arising from aggregation noted above. However, Butler and Ranney (1994) find that referendum results often differ by several percentage points from polling data taken beforehand. Thus data taken

\footnotetext{
${ }^{13}$ Calvo and Escolar add spatial information to their estimation, which in their work acts as a proxy for different costs of living in different areas.

${ }^{14}$ These estimates are not reported, but are available upon request.
} 
from referendum results has the advantage that it reflects actual choices made by voters, rather than answers given by a respondent to someone calling to interrupt his dinner. Individual survey data and aggregated voting data each have their problems and advantages, both unavoidable given the secrecy of the ballot. Presumably a better understanding of voting behavior can be gained by using both individual survey and aggregated results. ${ }^{15}$

The Maastricht Treaty was expected to affect economic conditions in several ways. Reduction of trade barriers were expected to raise the general level of prosperity, although it would also create structural adjustment problems for industries with a weak competitive positions and the areas that surround them. Tightening of exchange rate bands, strengthening of the European Monetary Union would have been expected to reduce exchange rate risk, and the subsequent creation of a common European currency would eliminate it. However, the process of monetary integration required limits on national fiscal policy, the so-called convergence criteria, decreasing national government's ability to respond to economic downturns, while the scope for independent monetary policy was set on a course of extinction. Thus the interests of those who could expect to benefit from the lowering or elimination of trading and labor mobility barriers, presumably voters with higher income and education levels living in more urbanized areas, are set against those dependent on discretionary government spending which would be squeezed, presumably those with lower income levels, a higher probability of unemployment, living in more rural areas. However, during the referendum campaign there was little reason to believe that fiscal constraints re-

\footnotetext{
15 The decision to vote for a referendum day comprises two decisions. An individual must
} decide to cast a ballot and then decide to vote 'Oui' rather than 'Non' or cast a blank ballot. Meon (2004) analyzes turnout for the 1992 referendum and finds it strongly related to turnout in presidential elections. Turnout regressions without a previous turnout variable using the present dataset indicate abstention is positively correlated with the the unemployment rate and negatively correlated with the proportion of French natives and support for the 1972 EEC referendum. These results available upon request. Turnout was lowest in red-belt suburbs of Paris where hard-line communists are strongest, although this effect does not show up in the regression estimates for the 1988 vote share of Andre Lajoinie, the official candidate of the Stalinist Communist Party. Deacon and Shapiro (1975) propose a model in which voters who are indifferent abstain. However, this approach is not fully consistent with behavior observed in the Maastricht referendum. That is, it appears some voters abstain due to political alienation (as suggested by the unemployment and non-native effects), some abstain or spoil ballots as a protest, and others abstain because they are indifferent or the costs of voting are high. Estimating a model of abstention that allows for multiple types of absention would require more data than are here available. 
quired by Maastricht would directly affect CAP payments, as the direct national share of CAP payments (co-responsibility) is minor.

Approval of Maastricht also opened the door to further expansion of the EU, while its failure would have retarded any attempt to include new countries. Bringing additional countries into the EU requires reworking of complex voting schemes, coalitions among member governments, and reconfiguration of fiscal burdens and benefits. The scale of CAP finances guarantees it a place on the agenda at any such renegotiation among member governments. While contributor countries have lacked the leverage to bring about significant and long-lasting reform through negotiations within the CAP framework, a major reopening of basic EU arrangements introduces the possibility that net contributor countries will refuse to continue to pay for the CAP at prior levels, creating a sudden contraction of the farm subsidy system. This fear of the effects of extending the EU may explain the agricultural opposition to the Maastricht ratification.

\subsubsection{Are Changes in Subsidies Endogenous?}

If subsidies affect voting behavior, then the logical follow-up question is whether politicians or administrators who answer to them can or do change subsidy levels for various areas based on political considerations. This question raises several technical and practical questions. First, it is not obvious that politicians or administrators can easily manipulate a formula-driven subsidy program. If they could manipulate program administration to reallocate subsidies, then changes in subsidies should be correlated with political and economic factors. The change in subsidies between 1992 and 1993, which reflects changes brought about by a major reform of the CAP, are correlated with several important economic and political variables. ${ }^{16}$

If manipulation of subsidy levels were possible, what the politicians would do is not immediately obvious. An alteration of the subsidy policy that might aid legislative candidates, chosen in specific geographic areas, might not aid presidential candidates seeking national support. A politician might reward his supporters with higher subsidies to encourage greater electoral effort, or may want to influence marginal voters while taking support of more fervent supporters for granted. This effect would be presumably larger for district-based elections,

\footnotetext{
${ }^{16}$ Results available upon request.
} 
such as parliamentary or congressional elections, where geographically-targeted benefits would help specific candidates.

The possibility that politicians can manipulate patterns of redistribution to enhance their political chances raises problems of identifying how subsidies and voting behavior are mutually determined. On the other hand, if a leading politician such as the French president could affect agricultural subsidy policy in order to ensure passage of the Maastricht treaty, the results presented below suggest that the best strategy would have been to delay introduction of the $1992 \mathrm{Mac}-$ Sherry reforms. The EU attempted to stall reforms discussed in the Uruguary round trade negotiations, which eventually led to an impasse in 1990 that threatened major damage to the world trading system, which led European business leaders in export-oriented sectors to twist arms sufficiently hard to force CAP reform (Baldwin and Wyplosz \$8.3). The French political establishment accepted these reforms only under substantial and unusual duress, implying that the broad structure of the MacSharry reforms can reasonably be considered exogenous.

\section{Data}

\subsection{Splitting Cities from Départements}

Data on subsidies and voting are available by region and for all départements, providing a unique opportunity for studying the effect of subsidies on voting, as there are a sufficient number of observations to employ appropriate statistical techniques and the scale of subsidies sufficient to plausibly affect political behavior. Observations from the four overseas départements and Corsica are excluded because their social and political cultures differ significantly from continental France. Data for Paris and its suburbs in the nearest two départements are also excluded because agriculture subsidy data are only reported for the "Petite Coronne" which contains Paris, Hauts de Seine, and Seine St. Denis. ${ }^{17}$

The data set also includes data for 209 of the largest cities in France. The smallest cities in the dataset have about 20,000 residents. ${ }^{18}$ Values for

\footnotetext{
${ }^{17}$ Subsidies in the Petite Coronne are allocated by Val de Marne, which is by far the least dense departement there.

${ }^{18}$ In some cases larger cities were excluded when data for the 1972 referendum could not be obtained. For example, planned communities developed in the mid-1970s could not be included.
} 
these cities were subtracted from the values of the département which contained them. Département observations, which have had city values subtracted from them, will be called 'département remainders.' This approach has two advantages. First, the larger sample size provides more precise estimates. Second, if city and non-city voters differ, separating city and non-city data reduces errorsin-variables problems resulting from aggregation. ${ }^{19}$ This is important because agricultural subsidies are probably more salient to non-city voters. City-specific data were gathered for all variables except for data on farm subsidies and agricultural employment data which are unavailable below the département level. In 1990, according to the French population census, cities in the dataset contained 14.3 million people. In 1990 twelve départements with no city in the dataset had a total of 2.2 million residents. Départements with at least one city in the dataset contained 35.8 million people. Table 1 shows descriptive statistics for the combined sample, city observations and département remainders, from which city data have been subtracted.

\subsection{Variables}

This section describes independent variables used in the empirical analysis, which are divided among the categories of urbanization and location; European orientation, economic conditions, political preferences and subsidies.

Urbanization and location are important because urban residents may have different preferences and are unlikely to receive agricultural subsidies. The logarithm of 1990 population density and a dummy variable for city observations (CITY) measure the degree of urbanization. NONCITY is a dummy variable for non-city observations, i.e. remainders of départements and those départements that contain no large or medium-sized cities. Two variables reflect special regional circumstances that may influence local material interests and hence voting behavior. First, a measure of proximity to the European Parliament in Strasbourg is included. Success of European integration may have been expected to

\footnotetext{
${ }^{19}$ Regressions were run on undivided départements as an illustrative exercise and are available upon request. These regressions explained a much smaller proportion of the variance than those $-2$

presented in Table 4. For example first specification in Table 4 has an $\bar{R}$ of 0.66 compared to an $\bar{R}^{2}$ of .23 for the corresponding specification run with undivided departements. However, the estimated effect of cereal subsidies was virtually identical.
} 
increase the importance of the European Parliament, and this could have given voters near the Parliament reason to support the referendum. Or voters living near the European Parliament may have already enjoyed benefits which led them to view European integration in a more positive light. For cities the driving time to Strasbourg was taken from <www.mapquest.fr $>$, and for Strasbourg the driving time was arbitrarily set at 15 minutes. For Bas-Rhin, the département that contains Strasbourg, the driving time was arbitrarily set at 40 minutes, and for the neighboring départements (Haut-Rhin, Moselle, Vosges) driving times were set at 70 minutes. Benefits to proximity to the European Parliament were assumed to be quadratic in distance:

$$
E P_{-} P R O X=\max \left\{\frac{80^{2}-(\text { driving time })^{2}}{80^{2}}, 0\right\}
$$

presuming that no benefits are received for areas requiring more than 80 minutes driving time.

Second, the variable PORT indicates whether a city has ferry service to England. Until 1999 ferry passengers between France and England were allowed to buy duty-free goods, providing an indirect subsidy to ferry operators and to merchants in port cities. For example, before the abolition of intra-EU duty-free sales, Calais received about 8.5 million British visitors per year, many drawn by the opportunity to buy duty-free goods (BBC, 1999). The Council of Ministers in 1991 decided to abolish intra-EU duty-free sales in 1999, although some believed that this decree would be modified or delayed. The Maastricht Treaty's clause 113 states that commerical policy should be based on "uniform principles." Perhaps this gave those who would lose benefits from the application of uniform principles, such as by limiting duty-free sales, a motive to vote 'Non'.

The degree of European orientation is measured by the log-odds ratio for the 'Oui' vote in the 1972 referendum and the proportion of the population who are not native-born citizens of France.

Economic conditions are measured by imputed local unemployment rates in 1992, calculated using official département-level data and 1990 self-reported income at the city level. Income data was taken from the French revenue authority's website.

Political preferences are represented by results from the first round of 
the 1988 Presidential election. Votes in the first rounds of Presidential elections may provide a better measure of true political preferences than second-round votes, as the second round offers a choice of only two candidates. Vote shares for Mitterand, LePen and Barre in the first round of the 1988 Presidential race are calculated as the proportion of the total number of valid ballots. French communists had historically opposed European integration, though some chose to abstain or boycott the referendum. The main communist party strongly opposed ratifying Maastricht, while other communists were strongly in favor. Therefore the vote share of the official communist candidate, Andre Lajoinie, is separated out from the other communist candidates (Juquin, Laguiller or Boussel) which comprise the variable OTHRCOMMI. Le Pen took a strong anti-Maastricht position (Ross, 2000). The traditional Gaullists (Chirac, Bousel) are the omitted category along with Waechter, a minor environmentalist candidate.

Département level variables measuring effects of farm subsidies are divided by non-city population, assuming that city residents get a 'warm glow' externality from increases in well-being of non-city residents, or enjoy goods complementary to increased agricultural activity such as seeing open countryside. City merchants may also benefits from increased subsidy levels for local farmers, while paying a small fraction of their cost. ${ }^{20}$

CEREAL92 and RESTSUB92 represents cereal and non-cereal subsidies (000s of current FF) from the 1992 divided by non-city population. CER_SD92, OTHR_SD92 and ELEVSD92 represent cereal, non-cereal and 'elevage and revaluation,' and were computed using the AGRESTE 'semi-definite' tabulations for 1992. These categories are mutually exclusive and sum to total subsidies. SUBVEN92 is computed using data from the AGRESTE CD.

\footnotetext{
${ }^{20}$ This 'warm glow' could also be negative. This could occur if city residents resent the subsidies received by nearby farmers. If agricultural markets are not well integrated regionally or nationally, then higher farm subsidies to farms in nearby areas might increase prices to residents of a city.
} 


\section{Analysis of Referendum Voting Behavior}

\section{$5.1 \quad$ Split-sample Estimates}

Table 2 presents results for unweighted OLS regressions with four sets of RHS variables run on the whole dataset, but with interaction terms for city and noncity observations. The results support the predictions of the model presented above. Specifications that include voting results from the 1988 Presidential election explain nearly $80 \%$ of the variance. Even without these variables over $60 \%$ of the variance is explained.

This split-set estimation places no restrictions on coefficient estimates, but assumes error terms for both groups are distributed identically. Equality of the groups of city and noncity coefficients, as presented in Table 2, cannot be rejected at the $10 \%$ level, except for income and unemployment in the second and third specifications. ${ }^{21}$ The first set of right-hand side variables includes measures of urbanization, percent non-natives, previous support for European integration, income and unemployment as well as the level of subsidies. The subsidy per capita variables are interacted with the CITY and NONCITY dummies. For both cities and noncity observations variables measure the level of subsidies per noncity population. Coefficient estimates for the intercept and the indicator variable CITY are not reported. All other variables represent values or imputations of values for either the city or the département remainder.

The second specification includes votes shares for various candidates in the first round of the 1988 Presidential election, with Chirac's share as the omitted category. The third set includes a proximity to the European Parliament variable and a dummy for port cities with ferry service to England. The third set omits variables reflecting voting in the first round of the 1988 Presidential election. Coefficients have been transformed into elasticity form, except for those associated with dummy variables. White robust standard errors are presented in parentheses below.

In all regressions, the log-odds ratio of the proportion of those voting to

\footnotetext{
${ }^{21} \mathrm{~F}$-tests were run for the groups of variables measuring European Orientation (\%Not French Native, Log-Odds Oui '72); Economic Conditions (Local Unemployment, Income); Political Preferences (various candidate vote shares in 1988); and Subsidies (various measures of per capita subsidies). In each case the hypothesis that city and non-city coefficient estimates were equal could not be rejected at the $10 \%$ level except for the Economic Conditions variables in specifications two (pval=0.075) and three (pval=0.048).
} 
approve the 1972 referendum is positive and strongly significant, suggesting that French voters retain a long political memory, so that the patterns of voters' reactions to political events remain visible decades later. Untransformed coefficients for the 1972 vote range from about .3 to .5, reflecting the greater level of support for the 1972 EEC treaty. Past voting in the 1988 Presidential election also shows up strongly, though its effects are more complicated. Relative to those areas that supported Chirac, areas that supported Mitterand, Barre and communists other than Lajoinie were significantly more likely to support Maastricht, although these effects were stronger in cities than in noncity areas. Those who supported LePen or Lajoinie did not vote significantly differently than those who support Chirac. These results reflect the splits within traditional political parties over the wisdom of ratifying the Maastricht treaty.

Because President Mitterand chose to ratify Maastricht via referendum rather than a Parliamentary vote and because he led the 'Oui' forces, some analysts interpreted the results as a referendum on Mitterand's presidency rather than on the actual content of the Maastricht treaty (Franklin et al. 1994, Franklin 1995). If this were the case, support for ratification among Mitterand's core supporters would be stronger, ceteris paribus, than among supporters of his centerright rivals. Those who voted for him in the first round in 1988 were more likely to support ratification of Maastricht relative to those who choose Chirac in 1988, especially in cities. On the other hand, the estimates of the strength of support for ratification was about the same as for supporters of the Gaullist figure Raymond Barre. Thus Mitterand's core supporters, those who picked him in the initial 1988 round, were more supportive than core supporters of Chirac, who gave the Maastricht ratification effort lukewarm support, but not evidently more strongly than followers of other politicians who supported ratification. Thus while Mitterand may have some effect, most probably in more urbanized areas, it does not appear to be the major determinant of voters' choices.

Estimates shows that economic factors played a strong role in determining support for Maastricht, and the influence of economics is closely linked to politics. The model suggests areas that pay a greater proportion of the taxes will be more likely to support political integration that would limit internal redistribution, while beneficiaries of redistributive policies will be less likely to support European integration. This prediction is borne out in the data. 
In the first specification, which drops the 1988 Presidential vote variables, income is not significantly correlated with referendum support and higher levels of unemployment are stronger correlated with weaker support. In the second and third specifications, the results are very different. As unemployment has been a major issue in French politics, one would expect a strong correlation between local unemployment and the performance of various candidates in the previous Presidential vote, and thus some changes in the estimated effects are expected. This suggests that both right-wing and left-wing parties have supporters from various income levels, but that sorting between right-wing and left-wing is sharper when it comes to unemployment.

Higher income in cities and lower unemployment in the noncity areas are significantly linked to stronger support, while coefficients for higher income in the noncity areas and lower unemployment in cities are insignificant. Meon (2002,2004) finds a correlation between lower unemployment and strong support for the referendum, and other analysts that more prosperous areas favored integration. Vlachos (2002) presents a paper on the Swedish EU membership referendum which argues that because greater EU powers restrict member governments' ability to pursue aggressive employment policies, voters in areas at higher risk of structural unemployment are more likely to oppose integration. In other words, voting for Maastricht is a vote for entering an economic and political system that promises to constrain redistribution through national programs, such as national subsidies, industrial policies, employment programs and other means. In particular, the Stability Pact requiring countries entering the Eurozone to limit their public debt and deficit spending, could have reasonably been expected by French voters to restrict various national initiatives aimed at the unemployed and other groups. However, the differential pattern of support, with income mattering more in urban areas and unemployment mattering more in rural areas, has not be noted before. This may reflect differences in economic opportunities, so unemployment may be less important in urban areas that have thicker job markets. ${ }^{22}$

The effects of cereal subsidies are significant and negative in all three specifications for both city and noncity areas, while coefficients for noncereal sub-

\footnotetext{
${ }^{22}$ Unemployment rates for local areas are imputed while previous election data are not. Measurement errors for unemployment may bias estimates downward, thus understating the importance of unemployment.
} 
sidies are small and not statistically significant. Interpreting these coefficients requires an explanation of how the 1992 MacSharry reforms worked. Target prices were sharply reduced for cereals $(24.8 \%$ for maize and soft wheat, $44.3 \%$ for hard wheat and $20.9 \%$ for other cereals) and reduced by a futher $7.7 \%$ in 1993 . To compensate for these changes direct payments to farmers were increased. Direct payments were based on the size of farms and local agricultural productivity, but were 'decoupled' from current and future yields. To receive direct payments farmers had to withdraw $15 \%$ of their arable land from cultivation. According to data available in late 1992, 3.4 billion French Francs (FF) were spent on cereal and oilseed subsidies which was predicted to increase to FF 19.5 billion (European Commision 1995 section 110; Baldwin and Wyplosz 2003). Thus an increase in subsidy payments is a proxy for the size of the effects of the MacSharry reforms upon a given farm, and cannot be simply interpreted as a simple increase in income. The negative relation between higher subsidy levels per capita and support for greater European economic integration suggests farmers either voted retrospectively wishing to punish politicians or voted prospectively and feared that expanding and deepening the European Union would lead to changes or reforms that would threaten subsidies. In any case, the bigger and more productive farms received larger payments, but also faced greater risks from reform. The insignificant coefficient for non-cereal subsidies suggests other types of farmers felt either less threatened or less harmed by the reforms.

The elasticity estimates associated with 1992 cereal subsidies to rural areas are remarkably stable across specifications. This estimate is $-0.21 \%$ for the first and fourth specification in Table 4 and for the first specification in Table 2. The second specification in Table 4, which uses official data from 2000 rather than the data available at the time, has an estimated elasticity of $0.20 \%$, which is the same as the estimate in the second specification in Table 2. If 'Oui' was exactly $50 \%$, a $1 \%$ change in cereal subsidies is associated with a $0.1 \%$ drop in support for European integration. If $10 \%$ more farms were so affected this would correlated with a $1 \%$ drop in support. Given that the percentage of the French population engaged in agriculture is about $3-4 \%$, this seems a reasonable magnitude. Of course, this elasticity should be interpreted carefully, as it measures not just the amount of subsidies received but also is a proxy for the size of the reform's effect on farms. 
The working of CAP reform may also explain the larger negative coefficient for the city and 1992 subsidy interaction term in Table 2. As farm subsidy payments are decoupled from actual production the demand for agricultural machinery and other inputs falls, damaging town merchants, who received no compensating payments from the government.

\subsection{Analysis of the City and Département Remainders}

The split-sample estimates for city and département remainder observations impose an equal error variance condition on the two types of observations. Because urban and rural areas may differ in ways that the independent variables do not measure, separate regression results for city observations are presented in Table 3, and results for département remainders are presented in Table 4. However, the estimates from the split-sample and the separate regressions are very similar. Results for the separate city regressions are very close to the city variables in the pooled regressions. All the variables which are statistically significant in one version are statistically significant in the other, and the estimated coefficients are very similar. For the département remainders the similarity between estimates is not as close, but all the main features are present in both. Some of the 1988 Presidential vote share variables are significant in one equation but not the other. However, for the other variables the signs of estimated coefficients never change, and coefficients statistically significant in one equation are statistically significant in the other. In particular, as with the pooled estimates, total subsidies and cereal subsidies have a statistically significant effect on voting behavior. Noncereal subsidies either have statistically insignificant coefficients (OTHERSUB92 and RESTSUB92), while revaluations had a positive effect on ratification support.

Thus pooling or splitting the sample has no effect on the estimation of the key factors influencing voting behavior: higher income and lower unemployment correlate with stronger support, past support for European integration translates to current support, and higher subsidies for cereals and oils is linked to strong opposition to integration. 


\section{Conclusion}

Two main themes emerge from the voting results. First, voting behavior on European integration issues does not neatly correlate with voting behavior in Presidential elections, which is unsurprising given the splits which the Maastricht issue caused in both the Left and the Right. Matsusaka (1992) presents a model in which politicians choose which issues will be decided by referendum, and which will remain within the normal political process, and argues that referendums are used for issues which cut across typical ideological boundaries. The evidence presented here provides some support for this hypothesis. The Maastricht referendum split the center-right, the communists and the environmentalists, making both the pro- and anti-ratification coalitions ideologically diverse according the dividing lines of ordinary politics (Ross 2000).

Second, voting over European integration is intertwined with redistributive programs, either through programs administered through national governments (industrial policies, unemployment initiatives) or through the European Union (CAP). The link between European integration and redistribution is hardly surprising. The introduction of the CAP was closely tied to the nature of trade agreements between France, Germany and other founding EEC members, and the European Social Fund was established in conjunction with Portugal's accession. However, the use of subsidies to acheive political and economic integration raises a time consistency issue. New subsidies may help overcome obstacles to European integration. However, once a system of subsidies is put in place it becomes difficult to reform or dismantle. Furthermore, these subsidies give their recipients a strong material incentive to resist further integration initiatives. As the regression results show, recipients of agricultural funds like new subsidies but dislike measures that might endanger existing subsidies.

At the national level the larger number of citizens who pay higher taxes or pay higher food prices may be unable to organize as effectively as the smaller number of agricultural producers. The common political economy explanation is that a small concentrated group enjoying benefits may be more politically influential than a larger diffuse group bearing the costs. However, political integration may limit the influence of such concentrated groups, as James Madison famously argued in the 10th Federalist paper. In a larger polity any given faction will have less influence because it must compete with a larger number of diverse factions, so 
only policies that are mutually beneficial or at least broadly beneficial are likely to survive. Voters frustrated by the influence of interest groups at the national level will then have a motive to push policy decisions to a supranational level where interest groups' influence is attenuated. On the other hand, opponents of reform will continue to resist changes either by influencing bargaining positions of national states or directly in international discussions. Paarlberg (1996) argues that those who hoped to bypass agricultural lobbies and ministries by pushing for agricultural trade and subsidy reform into the trade policy arena have little to show for their effects. However, even if transfering discussion of these issues to the international trade negotiations or to deliberations of supranational bodies such as the EU does not guarantee reform proponents will win, it does take those discussions out of arenas in which they are most likely to lose, that is, within the bounds of national agricultural policy. This motivation is often missing from discussions of who supports European integration. Consumers and taxpayers, who lose in the national policy arena, will naturally want to push decisions to a supranational area where provincial interests are weaker. Thus subsidies that have been used to help European integration negotiations past difficult sticking points may eventually bring greater pressure for the reduction of subsidies overall. 


\section{Data Sources}

Variables are grouped into four categories: location and urbanization, attitudes towards European integration, economic conditions, past electoral behavior and the level of subsidies. Land area data are taken from INSEE and $<$ www.quid.fr $>$ and population data were taken from INSEE website. The official département level unemployment rate data are INSEE (1996), and then used with town-level census data (Recensement du population 1990) to impute local unemployment rates for 1992 using a simple pro-rate allocation formula. ${ }^{23}$ The income variable is imputed using data from the French revenue authority for the 2000, the earliest year available, and département-specific income data for 1992. Thus the intra-départemental variation is taken from the nearest available year, and the interdepartmental variation is taken from official sources for the given year. ${ }^{24}$ Election and referendum results (1972 enlargement of European Economic Community, the first-round of the 1988 Presidential election and 1992 referendum on the Maastricht Treaty) appeared in Le Monde supplements. Nationality data were taken from the INSEE website (Recensement du population 2000). Other data are taken from issues of the Annuaire Statistique de la France. $^{25}$

Data on subsidies, agricultural production and number of farms (dossiers) were obtained from the French Ministry of Agriculture and AGRICOLE. Three versions of the subsidy data are used in the analysis. The first set of subsidy data were taken from annual reports for AGRESTE (1993). The second set of data provided by AGRESTE in as tabulations, and specified the 'semi-definite' totals for the current year and 'provisional' totals for the coming year. These data probably match most closely the information available to farmers and voters in September 1992. Some specifications also use the 'semi-definite' figures for 1992, denoted by variable names contained the code "SD." A third version of the

\footnotetext{
${ }^{23}$ The imputation of unemployment rates combines 1990 census data, which relies on selfreported data, with the annual departement level unemployment figures, which are compatible with International Labor Office standards. An unemployment data series at the subdepartemental level has only recently been developed.

${ }^{24}$ Income data at the sub-departemental level must exist, but were unavailable. Scholars who have used French income data were contacted about where to obtain these data. Unfortunately, it was impossible to find a source for these data. Piketty (2003) suggests patterns of French income growth are very stable, so these imputations may provide a reasonable approximation of local income. Of course, any assistance in obtaining these data would be appreciated.

${ }^{25}$ Some variables, such as income by city (commune) for the early 1990s have so far been unobtainable.
} 
data were taken from a data CD obtained from AGRESTE (2001), which contains data on subsidies from 1990 through 2000, but does not have a breakdown by category. In the results (Tables $2,3,4$ ) variables created using these data are flagged as 'AGRESTE CD. The different versions of the subsidy data are highly correlated, and differences in results are minor. ${ }^{26}$

\footnotetext{
${ }^{26}$ The major difference concerns the departement of Tarn et Garonne, which shows a discrepancy of 454 million FF between categories of subsidy for the 'definite' and 'semi-definite' figures. However, the total level of subsidy is very similar. AGRESTE was unable to provide a clarification.
} 


\section{References}

AGRESTE. 2001. Les Comptes Regionaux et départementaux de l'Agriculture - Series 1990-2000. Toulouse.

AGRESTE. 1992,1993,1994. Aides Compensentoires Aux Surfaces Cultivees 1992,1993,1994. Paris.

Amemiya, Takeshi and Frederic Nold. 1975. "A modified logit model." Review of Economics and Statistics 57(2), 255-256.

Annuaire Statistique de la France. various years. Paris.

Artis, Mike J. and Norman Lee (eds.). 1994. The Economics of the European Union: Policy and Analysis. Oxford University Press.

Austin, D. Andrew. 1996. "The price of nationalism: Evidence from the Soviet Union." Public Choice 87, 1-18.

Baldwin, Richard. and Charles Wyplosz. 2003. The Economics of European Integration. New York: McGraw-Hill.

Barrass, Robert and Shobana Madhavan. 1996. European Economic Integration and Sustainable Development: Institutions, Issues and Policies. London: McGraw Hill.

British Broadcasting Corporation. 1999. "End is nigh for duty-free." June 2. Accessed at <http://news.bbc.co.uk/1/hi/business/the_company_file/359370.stm>

Butler, David and Austin Ranney (Eds.). 1994. Referendums around the world: The growing use of direct democracy. Washington, DC: AEI Press.

Centre d'Etude des Revenus et des Couts. 1985. Les Revenus des Francais: La Croissance et la Crise (1960-1983). Paris.

Deacon, Robert T. and Perry Shapiro. 1975. "Private preference for collective goods revealed through voting on referenda." American Economic Review 65(5), 94355 .

Dickens, William T. 1990. "Error components in grouped data: Is it ever worth weighting?" Review of Economics and Statistics 72(2), 328-333.

Eijk, Cees van der, Mark N. Franklin and Michael Marsh. 1996. "What voters teach us about Europe-wide elections; What Europe-wide elections teach us about voters'. Electoral Studies (15:2), 149-166.

European Commission. 1995. The Agricultural Situation in the European Union: 1994 Annual Report. Brussels.

Franklin, Mark, Michael Marsh and Lauren McLaren. 1995. "Uncorking the bottle: Popular opposition to European unification in the wake of Maastricht." Journal of Common Market Studies (33) 455-472.

Franklin, Mark, Michael Marsh and Christopher Wlezien. 1994. "Attitudes toward Europe and referendum votes." Electoral Studies (13) 117-121.

Franklin, Mark. 1994. "Referendum outcomes and trust in government: Popular support for Europe in the wake of Maastricht" with Cees van der Eijk and Michael Marsh, West European Politics (18) 101-117.

Greene, William 2003. Econometric Analysis. New York: Prentice Hall. 
Gylfason, T. 2005. "The macroeconomics of European agriculture." Princeton Studies in International Finance 78.

INSEE. 1996. Le chômage régional en 1994. (Report 436). Paris.

INSEE. 2003. "Local unemployment rates from the Recensement de Population 1990."

Service d'Enquêtes Statistiques et de Documentation (S.E.S.DO.). 2002. "L'impôt sur le revenu 2000 par commune" accessed March 2004 at

<http://www2.impots.gouv.fr/documentation/ircom/ircom2000/index.htm>.

Jovanovič, Miroslav N. 1997. European Economics Integration: Limits and Prospects. London: Routledge.

Lewis-Beck, Michael S. 1983. "Economics and the French voter: A microanalysis." Public Opinion Quarterly 47, 347-360.

Matsusaka, John. 1992. "Economics of direct legislation." Quarterly Journal of Economics, 541-571.

Milward, Alan. 1993. The European Rescue of the Nation State. London: Routledge.

Le Monde. 1992. "Les resultats du referendum sur l'Union Europeene." Sept. 22.

Mazzucelli, Colette. 1997. France and Germany at Maastricht: Politics and Negotiations to Create the European Union. London: Garland.

Meon, Pierre-Guillaume. 2002. "Distribution consequences of a monetary union: what can we learn from a referendum?" Applied Economics Letters 9(9), 581584 .

. 2004. "Voting and turnout for monetary integration: the case of the French referendum on the Maastricht

Treaty." Working paper. Université Libre de Bruxelles.

Ministère de l'Agriculture, de l'Alimentation, de la Pêche et des Affaires Rurales. 2003. Les concours publics à l'agriculture en 2003. Paris.

Moravcsik, Andrew. 1998. The Choice for Europe: Social Purpose and State Power from Messina to Maastricht. London: UCL Press.

Paarlberg, Robert L. 1996. "The Uruguay Round and agriculture: International path to domestic policy reform?" Working paper 96-1. Weatherhead Center for International Affairs, Harvard.

Piketty, Thomas. 2003. "Income inequality in France, 1901-1998." Journal of Political Economy 111, 1004-1042.

Ross, George. 2000. "Europe becomes French domestic politics" in How France Votes (ed. M. Lewis-Beck). London: Chatham House.

Snyder, James. 2005. "Estimating the distribution of voter preferences using partially aggregated voting data." Political Methodologist 13(1).

Swann, Dennis. 1996. European Economic Integration: The Common Market, European Union and Beyond. Cheltenham, UK: E. Elgar.

Tokarick, Stephen. 2005. "Who bears the cost of agricultural support in OECD countries?" World Economy 28 (4), 573-593. 
Vlachos, Jonas. 2005. "Who wants political integration? Evidence from the Swedish EU-membership referendum." Journal of Public Economics 88, 1589-1604.

Wikipedia. 2005. "Départements in France."

Accessed October 2005 at <http://en.wikipedia.org/wiki/D\%C3\%A9partement_in_France>. 
Table 1: Means for Pooled Sample, City Observations and Departement Remainders

\section{Variable}

VOTEPROP

OUIPROP72

LGOD_OUI

\section{Location}

EP_PROX

PORT

LOGDENS

\section{Description}

\%Voting 1992 Referendum

$\%$ Oui 1992 Referendum

Log-odd \% Oui 1992 Referendum

Proximity to Euro Parliament

Ferry Service to UK (1/0)

Log 1990 Population Density

European Orientation

$\begin{array}{ll}\text { OUIPROP72 } & \text { \% Oui } 1972 \text { EEC Referendum } \\ \text { NonNative } & \% \text { Not French Native }\end{array}$

Economic Conditions

$\begin{array}{ll}\text { UNEMPL92 } & \text { Local Unemployment } \\ \text { INCOME92 } & \text { Income (FF,1000s) }\end{array}$

1988 Presidential Vote (1st Round)

MITTERAND \% Mitterand

BARRE \% Barre

LEPEN \% LePen

LAJOINIE \% Lajoinie

OTHRCOMMI \% Other Commies

FARMERSPC92 Non-Salaried Agr. Workers per cap. '92

FARMERSPC93 Non-Salaried Agr. Workers per cap. '93

Subsidies (000s FF/noncity pop)

$\begin{array}{ll}\text { CEREAL92 } & \text { Cereal Subsidies } 1992 \\ \text { ELEVSD92 } & \text { Elevage and Revalour. }\end{array}$

ELEVSD92

Elevage and Revalour. 1992

RESTSUB92

SUBVEN92

SUBVEN93

SUB9293

$\mathbf{N}$

Notes: Paris, Hauts de Seine, Seine Saint Denis, Corsica and overseas departements omitted.

Total subsidies 1993 (AGRESTE CD)

Change in subsidies 92-93 (AGRESTE CD)

Non-Cereal subsidies 1992

Total subsidies1992 (AGRESTE CD)

\begin{tabular}{|c|c|c|c|c|c|}
\hline \multicolumn{2}{|c|}{ Pooled Sample } & \multicolumn{2}{|c|}{ Cities } & \multicolumn{2}{|c|}{ Departement Reme } \\
\hline Mean & Std. Dev. & Mean & Std. Dev. & Mean & Std. Dev. \\
\hline 0.670 & 0.036 & 0.657 & 0.034 & 0.701 & 0.019 \\
\hline 0.517 & 0.068 & 0.527 & 0.071 & 0.493 & 0.053 \\
\hline 0.069 & 0.277 & 0.111 & 0.291 & -0.027 & 0.214 \\
\hline 0.020 & 0.108 & 0.020 & 0.115 & 0.019 & 0.091 \\
\hline 0.023 & 0.151 & 0.033 & 0.180 & & \\
\hline 6.642 & 1.836 & 7.705 & 0.891 & 4.20 & 0.84 \\
\hline 0.675 & 0.092 & 0.674 & 0.099 & 0.676 & 0.075 \\
\hline 0.146 & 0.091 & 0.168 & 0.096 & 0.095 & 0.052 \\
\hline 11.4 & 3.4 & 12.2 & 3.6 & 9.5 & 1.9 \\
\hline 80.9 & 16.7 & 81.5 & 18.2 & 79.6 & 12.8 \\
\hline 0.339 & 0.052 & 0.337 & 0.056 & 0.345 & 0.042 \\
\hline 0.164 & 0.034 & 0.164 & 0.034 & 0.165 & 0.034 \\
\hline 0.154 & 0.049 & 0.162 & 0.050 & 0.135 & 0.042 \\
\hline 0.071 & 0.042 & 0.073 & 0.047 & 0.068 & 0.031 \\
\hline 0.045 & 0.009 & 0.045 & 0.010 & 0.046 & 0.007 \\
\hline 0.025 & 0.019 & 0.021 & 0.017 & 0.033 & 0.020 \\
\hline 0.023 & 0.018 & 0.020 & 0.016 & 0.031 & 0.019 \\
\hline 0.089 & 0.152 & 0.074 & 0.138 & 0.125 & 0.178 \\
\hline 0.077 & 0.126 & 0.059 & 0.106 & 0.117 & 0.158 \\
\hline 0.407 & 0.483 & 0.327 & 0.415 & 0.592 & 0.573 \\
\hline 0.311 & 0.399 & 0.251 & 0.362 & 0.449 & 0.445 \\
\hline 0.645 & 0.675 & 0.535 & 0.621 & 0.897 & 0.729 \\
\hline 0.334 & 0.352 & 0.284 & 0.329 & 0.448 & 0.376 \\
\hline 300 & & 209 & & 91 & \\
\hline
\end{tabular}


Table 2: Combined (Split Sample) Analysis of Maastricht Ratification

\begin{tabular}{|c|c|c|c|c|c|c|c|c|c|c|c|c|c|}
\hline \multirow[b]{2}{*}{ Variable } & \multirow[b]{2}{*}{ Label } & \multicolumn{3}{|c|}{ ONE } & \multicolumn{3}{|c|}{$1 \mathrm{WO}$} & \multicolumn{3}{|c|}{ 1HREE } & \multicolumn{3}{|c|}{ FUUR } \\
\hline & & $\beta$ & t-stat & Elast. & $\boldsymbol{\beta}$ & t-stat & Elast. & $\bar{\beta}$ & t-stat & Elast. & $\boldsymbol{\beta}$ & t-stat & Elast. \\
\hline \multicolumn{14}{|c|}{ Urbanization and Location } \\
\hline CITY & & -0.76 & -1.11 & & -1.01 & -1.50 & & -0.88 & -1.38 & & -0.16 & -0.50 & \\
\hline LOGDENS & Log Population Density & 0.01 & 0.91 & 1.80 & 0.01 & 0.73 & 2.91 & 0.008 & 0.67 & 2.59 & 0.06 & 4.00 & 23.0 \\
\hline EP_PROX & Proximity to Euro Parlmt. & 0.67 & 8.44 & 0.30 & 0.67 & 8.44 & 0.60 & 0.65 & 8.03 & 0.61 & 0.41 & 6.35 & 0.45 \\
\hline PORT & Ferry Service to UK (1/0) & -0.17 & -2.46 & & -0.16 & -2.33 & & -0.17 & -2.48 & & -0.14 & -1.47 & \\
\hline \multicolumn{14}{|l|}{ European Orientation } \\
\hline NonNative* CITY & $\%$ Not French Native & 0.46 & 3.43 & 1.22 & 0.47 & 3.50 & 2.48 & 0.45 & 3.33 & 2.48 & -0.33 & -1.72 & -2.11 \\
\hline NonNative*NONCITY & & 1.26 & 2.58 & 0.94 & 1.22 & 2.42 & 1.81 & 1.36 & 2.75 & 2.08 & 0.20 & 0.46 & 0.36 \\
\hline LGODOUI72*CITY & Log-Odds Oui '72 EEC Ref. & 0.33 & 4.26 & 3.96 & 0.32 & 4.26 & 7.87 & 0.34 & 4.50 & 8.46 & 0.36 & 8.59 & 10.3 \\
\hline LGODOUI72*NONCITY & & 0.32 & 3.20 & 1.70 & 0.33 & 3.41 & 3.52 & 0.34 & 3.40 & 3.75 & 0.30 & 5.06 & 3.77 \\
\hline \multicolumn{14}{|l|}{ Economic Conditions } \\
\hline UNEMPL92*CITY & Local Unemployment & 0.003 & 0.69 & 0.77 & 0.003 & 0.79 & 1.77 & 0.004 & 0.92 & 2.08 & -0.02 & -3.27 & -12.0 \\
\hline UNEMPL93*NONCITY & & -0.015 & -1.77 & -3.32 & -0.018 & -2.00 & -7.65 & -0.018 & -1.92 & -7.97 & -0.03 & -2.84 & -13.7 \\
\hline INCOME92*CITY & Income (FF,1000s) & 0.004 & 4.46 & 7.53 & 0.004 & 4.71 & 15.9 & 0.004 & 4.31 & 14.4 & 0.0001 & 0.10 & 0.43 \\
\hline INCOME92*NONCITY & & 0.001 & 0.83 & 2.73 & 0.001 & 0.80 & 5.26 & 0.0004 & 0.26 & 1.50 & -0.0007 & -0.37 & -3.02 \\
\hline \multicolumn{14}{|c|}{1988 Presidential Vote (1st Round) } \\
\hline MITTERAND*CITY & $\%$ Mitterand & 1.08 & 2.47 & 5.83 & 1.13 & 2.80 & 12.2 & 0.86 & 2.11 & 9.62 & & & \\
\hline MITTERAND*NONCITY & & 0.57 & 1.07 & 1.37 & 0.48 & 0.85 & 2.30 & 0.18 & 0.35 & 0.89 & & & \\
\hline BARRE*CITY & $\%$ Barre & 2.36 & 3.44 & 6.20 & 2.49 & 3.96 & 13.1 & 2.00 & 3.13 & 10.9 & & & \\
\hline BARRE*NONCITY & & 1.16 & 1.99 & 1.34 & 1.02 & 1.74 & 2.34 & 0.80 & 1.17 & 1.91 & & & \\
\hline LEPEN*CITY & \% LePen & -0.49 & -0.81 & -1.27 & -0.22 & -0.37 & -1.13 & -0.68 & -1.17 & -3.67 & & & \\
\hline LEPEN*NONCITY & & -0.89 & -1.27 & -0.84 & -1.13 & -1.55 & -2.13 & -1.25 & -1.80 & -2.44 & & & \\
\hline LAJOINIE* CITY & $\%$ Lajoinie & -0.42 & -0.48 & -0.49 & -0.43 & -0.51 & -0.99 & -0.58 & -0.68 & -1.39 & & & \\
\hline LAJOINIE*NONCITY & & 0.26 & 0.30 & 0.13 & 0.56 & 0.63 & 0.53 & 0.42 & 0.44 & 0.41 & & & \\
\hline OTHRCOMMI*CITY & $\%$ Other Commies & 9.97 & 7.37 & 7.25 & 10.6 & 7.55 & 15.4 & 10.2 & 7.42 & 15.3 & & & \\
\hline OTHRCOMMI*NONCITY & & 6.56 & 2.94 & 2.11 & 6.12 & 2.80 & 3.93 & 7.10 & 3.17 & 4.71 & & & \\
\hline \multicolumn{14}{|c|}{ Subsidies (000s FF/noncity pop) } \\
\hline CEREAL92*CITY & Cereal Subsidies '92 & -0.15 & -2.42 & -0.17 & -0.164 & -2.42 & -0.39 & & & & -0.01 & -0.17 & -0.04 \\
\hline CEREAL92*NONCITY & & -0.21 & -2.63 & -0.18 & -0.203 & -2.72 & -0.36 & & & & -0.18 & -2.37 & -0.37 \\
\hline RESTSUB92*CITY & Non-Cereal subsidies '92 & 0.04 & 1.15 & 0.22 & 0.004 & 0.13 & 0.04 & & & & 0.05 & 1.37 & 0.59 \\
\hline RESTSUB92*NONCITY & & 0.03 & 0.64 & 0.13 & 0.042 & 0.75 & 0.35 & & & & 0.03 & 0.77 & 0.34 \\
\hline ELEVSD92*CITY & Elevage and Reval '92 & & & & 0.27 & 2.38 & 0.00 & & & & & & \\
\hline ELEVSD92*NONCITY & & & & & -0.11 & -0.87 & 0.00 & & & & & & \\
\hline SUBVEN92*CITY & Subsidies '92 (AGRESTE CD) & & & & & & & -0.021 & -0.65 & -0.17 & & & \\
\hline SUBVEN92*NONCITY & & & & & & & & -0.072 & -1.70 & -0.47 & & & \\
\hline F-test & & 59.72 & & & 58.50 & & & 57.72 & & & 56.01 & & \\
\hline$R$-sq. & & 0.793 & & & 0.796 & & & 0.788 & & & 0.615 & & \\
\hline
\end{tabular}

Intercepts not reported. Elasticities multiplied by 100.

White standard errors used to compute $t$-statistic. Sample size: $N=300$. See text for additional notes.

For spec. (2) subsidy data are from AGRESTE "semi-definite" tabulations. 
Table 3: Analysis of Maastricht Ratification in Cities

\begin{tabular}{|c|c|c|c|c|c|c|c|c|c|c|c|c|c|}
\hline & & & ONE & & & TWO & & & THREE & & & FOUR & \\
\hline Variable & Label & Beta & t-stat & Elast. & Beta & t-stat & Elast. & Beta & t-stat & Elast. & Beta & t-stat & Elast. \\
\hline Urbanization & ind Location & & & & & & & & & & & & \\
\hline LOGDENS & Log Population Density & 0.020 & 1.35 & 1.88 & 0.017 & 1.15 & 1.46 & 0.015 & 1.13 & 1.78 & 0.071 & 3.95 & 19.85 \\
\hline EP_PROX & Proximity to Euro Parlmt. & 0.67 & 7.72 & 0.17 & 0.67 & 7.69 & 0.15 & 0.654 & 7.34 & 0.20 & 0.421 & 5.46 & 0.31 \\
\hline PORT & Ferry Service to UK (1/0) & -0.17 & -2.50 & & -0.16 & -2.37 & & -0.176 & -2.52 & & -0.141 & -1.52 & \\
\hline European Ori & ntation & & & & & & & & & & & & \\
\hline NonNative & \%Not French Native & 0.428 & 3.18 & 0.90 & 0.438 & 3.29 & 0.83 & 0.419 & 3.08 & 1.06 & -0.351 & -1.81 & -2.14 \\
\hline LGODOUI72 & \% Oui 1972 EEC Ref. & 0.327 & 4.26 & 3.08 & 0.326 & 4.27 & 2.79 & 0.338 & 4.50 & 3.85 & 0.355 & 8.4 & 9.75 \\
\hline Economic Cor & ditions & & & & & & & & & & & & \\
\hline UNEMPL92 & Local Unemployment & 0.002 & 0.63 & 0.37 & 0.003 & 0.73 & 0.40 & 0.003 & 0.88 & 0.63 & -0.018 & -3.23 & -7.81 \\
\hline INCOME92 & Income (FF,1000s) & 0.004 & 4.44 & 4.01 & 0.004 & 4.69 & 3.86 & 0.004 & 4.26 & 4.45 & 0.000 & 0.05 & 0.14 \\
\hline 1988 Presiden & tial Vote (1st Rnd) & & & & & & & & & & & & \\
\hline MITTERAND & \% Mitterand & 1.10 & 2.51 & 4.59 & 1.15 & 2.85 & 4.38 & 0.862 & 2.11 & 4.35 & & & \\
\hline BARRE & \% Barre & 2.38 & 3.49 & 4.84 & 2.50 & 4.00 & 4.63 & 1.99 & 3.12 & 4.90 & & & \\
\hline LEPEN & \% LePen & -0.41 & -0.68 & -0.83 & -0.16 & -0.26 & -0.28 & -0.626 & -1.06 & -1.52 & & & \\
\hline LAJOINIE & \% Lajoinie & -0.38 & -0.44 & -0.34 & -0.39 & -0.47 & -0.20 & -0.557 & -0.65 & -0.61 & & & \\
\hline OTHRCOMMI & \% Other Commies & 9.98 & 7.44 & 5.62 & 10.57 & 7.61 & 5.41 & 10.2 & 7.49 & 6.93 & & & \\
\hline Subsidies (000 & s FF/noncity pop) & & & & & & & & & & & & \\
\hline CEREAL92 & Cereal Subsidies '92 & -0.14 & -2.33 & -0.13 & & & & & & & -0.010 & -0.13 & -0.03 \\
\hline RESTSUB92 & Non-Cereal subsidies '92 & 0.048 & 1.30 & 0.19 & & & & & & & 0.053 & 1.49 & 0.62 \\
\hline SUBVEN92 & Subsidies 92 (AGRESTE CD) & & & & & & & -0.015 & -0.48 & 0.11 & & & \\
\hline "Semi-definite & 1992 & & & & & & & & & & & & \\
\hline CER_SD92 & Cereal subsidies '92 & & & & -0.159 & -2.37 & -0.133 & & & & & & \\
\hline ELEVSD92 & Elevage and Reval '92 & & & & 0.270 & 2.38 & 0.180 & & & & & & \\
\hline OTHR_SD92 & Other Subsidies p.c. '92 & & & & 0.011 & 0.32 & 0.000 & & & & & & \\
\hline F-test & & 73.75 & & & 74.41 & & & 73.98 & & & 54.86 & & \\
\hline$R$-sq. & & 0.802 & & & 0.805 & & & 0.798 & & & 0.591 & & \\
\hline
\end{tabular}

Intercepts not reported. Elasticities multiplied by 100. See text for other notes.

White standard errors used to compute t-statistic. Sample size: $N=209$ 
Table 4: Analysis of Maastricht Ratification for Departement Remainders

\begin{tabular}{|c|c|c|c|c|c|c|c|c|c|c|c|c|c|}
\hline \multirow{2}{*}{ Variable } & \multirow[b]{2}{*}{ Label } & \multicolumn{3}{|c|}{ ONE } & \multicolumn{3}{|c|}{ TWO } & \multicolumn{3}{|c|}{ THREE } & \multicolumn{3}{|c|}{ FOUR } \\
\hline & & Beta & t-stat & Elast. & Beta & t-stat & Elast. & Beta & t-stat & Elast. & Beta & t-stat & Elast. \\
\hline \multicolumn{14}{|l|}{ Urbanization } \\
\hline LOGDENS & Log Population Density & -0.013 & -0.48 & -0.98 & -0.012 & -0.44 & -1.01 & -0.015 & -0.62 & -1.42 & 0.026 & 1.03 & 5.19 \\
\hline \multicolumn{14}{|c|}{ European Orientation } \\
\hline NonNative & \%Not French Native & 1.06 & 1.58 & 1.88 & 1.02 & 1.46 & 2.00 & 1.08 & 1.67 & 2.31 & 0.597 & 1.22 & 2.68 \\
\hline LGODOUI72 & \% Oui 1972 EEC Ref. & 0.56 & 3.68 & 7.89 & 0.56 & 3.75 & 8.8 & 0.57 & 3.86 & 9.7 & 0.342 & 5.44 & 12.2 \\
\hline \multicolumn{14}{|c|}{ Economic Conditions } \\
\hline UNEMPL92 & Local Unemployment & -0.022 & -2.15 & -3.97 & -0.024 & -2.23 & -4.78 & -0.025 & -2.28 & -5.26 & -0.026 & -2.75 & -11.8 \\
\hline INCOME92 & Income (FF,1000s) & 0.003 & 1.31 & 3.81 & 0.002 & 1.20 & 3.88 & 0.002 & 1.03 & 3.38 & -0.001 & -0.28 & -2.1 \\
\hline \multicolumn{14}{|c|}{1988 Presidential Vote (1st Round) } \\
\hline MITTERAND & \% Mitterand & 1.12 & 2.00 & 7.24 & 1.03 & 1.79 & 7.35 & 0.85 & 1.52 & 6.55 & & & \\
\hline BARRE & \% Barre & 0.47 & 0.61 & 1.46 & 0.34 & 0.44 & 1.17 & 0.23 & 0.28 & 0.86 & & & \\
\hline LEPEN & \% LePen & 0.50 & 0.49 & 1.27 & 0.32 & 0.32 & 0.90 & 0.24 & 0.24 & 0.72 & & & \\
\hline LAJOINIE & \% Lajoinie & 1.91 & 1.52 & 2.42 & 2.09 & 1.67 & 2.93 & 2.12 & 1.67 & 3.20 & & & \\
\hline OTHRCOMMI & \% Other Commies & 7.99 & 3.35 & 6.88 & 7.66 & 3.19 & 7.28 & 8.42 & 3.57 & 8.64 & & & \\
\hline \multicolumn{14}{|c|}{ Subsidies (000s FF/noncity pop) } \\
\hline CEREAL92 & Cereal Subsidies '92 & -0.21 & -2.43 & -0.50 & & & & & & & -0.212 & -2.70 & -1.3 \\
\hline RESTSUB92 & Non-Cereal subsidies '92 & 0.010 & 0.20 & 0.11 & & & & & & & 0.007 & 0.17 & 0.2 \\
\hline SUBVEN92 & Subsidies 92 (AGRESTE CD) & & & & & & & -0.84 & -1.84 & -0.84 & & & \\
\hline CER_SD92 & Cereal subsidies '92 & & & & -0.204 & -2.43 & -0.53 & & & & & & \\
\hline ELEVSD92 & Elevage and Reval '92 & & & & -0.092 & -0.76 & -0.22 & & & & & & \\
\hline OTHR_SD92 & Other Subsidies '92 & & & & 0.016 & 0.29 & 0.002 & & & & & & \\
\hline F-test & & 17.36 & & & 15.72 & & & 17.22 & & & 16.65 & & \\
\hline$R-s q$ & & 0.655 & & & 0.657 & & & 0.651 & & & 0.591 & & \\
\hline
\end{tabular}

Intercepts not reported. Elasticities multiplied by 100.

White standard errors used to compute t-statistic. Sample size: $N=91$. See text for additional notes. 
Individual researchers, as well as the on-line and printed versions of the CERGE-EI Working Papers (including their dissemination) were supported from the following institutional grants:

- Economic Aspects of EU and EMU Entry [Ekonomické aspekty vstupu do Evropské unie a Evropské měnové unie], No. AVOZ70850503, (2005-2010);

- Economic Impact of European Integration on the Czech Republic [Ekonomické dopady evropské integrace na ČR], No. MSM0021620846, (2005-2011);

Specific research support and/or other grants the researchers/publications benefited from are acknowledged at the beginning of the Paper.

(c) D. Andrew Austin, 2005

All rights reserved. No part of this publication may be reproduced, stored in a retrieval system or transmitted in any form or by any means, electronic, mechanical or photocopying, recording, or otherwise without the prior permission of the publisher.

Published by

Charles University in Prague, Center for Economic Research and Graduate Education (CERGE) and

Economics Institute (EI), Academy of Sciences of the Czech Republic

CERGE-El, Politických vězňů 7, 11121 Prague 1, tel.: +420 224005 153, Czech Republic.

Printed by CERGE-EI, Prague

Subscription: CERGE-EI homepage: http://www.cerge-ei.cz

Editors: Directors of CERGE and EI

Managing editors: Deputy Directors for Research of CERGE and EI

ISSN 1211-3298

ISBN 80-7343-074-6 (Univerzita Karlova v Praze, CERGE)

ISBN 80-7344-063-6 (Národohospodářský ústav AV ČR, Praha) 
CERGE-EI

P.O.BOX 882

Politických vězňů 7

11121 Praha 1

Czech Republic http://www.cerge-ei.cz 